OPEN ACCESS

Edited by:

Sergio Rossi,

Université du Québec à Chicoutimi,

Canada

Reviewed by:

Eva Pšidová,

Slovak Academy of Science, Slovakia

Elizabeth Watson,

Drexel University, United States

*Correspondence:

Christoph Leuschner

cleusch@gwdg.de

Specialty section:

This article was submitted to

Functional Plant Ecology,

a section of the journal

Frontiers in Plant Science

Received: 12 November 2018 Accepted: 28 February 2019

Published: 18 March 2019

Citation:

Göbel L, Coners H, Hertel D, Willinghöfer $S$ and Leuschner $C$

(2019) The Role of Low Soll

Temperature for Photosynthesis and Stomatal Conductance of Three

Graminoids From Different Elevations.

Front. Plant Sci. 10:330

doi: $10.3389 /$ fpls.2019.00330

\section{The Role of Low Soil Temperature for Photosynthesis and Stomatal Conductance of Three Graminoids From Different Elevations}

\author{
Leonie Göbel ${ }^{1,2}$, Heinz Coners ${ }^{1}$, Dietrich Hertel ${ }^{1}$, Sandra Willinghöfer ${ }^{1}$ and \\ Christoph Leuschner ${ }^{1 *}$ \\ ${ }^{1}$ Plant Ecology, Albrecht von Haller Institute for Plant Sciences, University of Göttingen, Göttingen, Germany, ${ }^{2}$ Soil Science \\ of Tropical and Subtropical Ecosystems, Büsgen Institute, University of Göttingen, Göttingen, Germany
}

In high-elevation grasslands, plants can encounter periods with high air temperature while the soil remains cold, which may lead to a temporary mismatch in the physiological activity of leaves and roots. In a climate chamber experiment with graminoid species from three elevations (4400, 2400, and $250 \mathrm{~m}$ a.s.I.), we tested the hypothesis that soil temperature can influence photosynthesis and stomatal conductance independently of air temperature. Soil monoliths with swards of Kobresia pygmaea (high alpine), Nardus stricta (lower alpine), and Deschampsia flexuosa (upper lowland) were exposed to soil temperatures of $25,15,5$, and $-2^{\circ} \mathrm{C}$ and air temperatures of 20 and $10^{\circ} \mathrm{C}$ for examining the effect of independent soil and air temperature variation on photosynthesis, leaf dark respiration, and stomatal conductance and transpiration. Soil frost $\left(-2^{\circ} \mathrm{C}\right)$ had a strong negative effect on gas exchange and stomatal conductance in all three species, independent of the elevation of origin. Leaf dark respiration was stimulated by soil frost in $D$. flexuosa, but not in $K$. pygmaea, which also had a lower temperature optimum of photosynthesis. Soil cooling from 15 to $5^{\circ} \mathrm{C}$ did not significantly reduce stomatal conductance and gas exchange in any of the species. We conclude that all three graminoids are able to maintain a relatively high root water uptake in cold, non-frozen soil, but the high-alpine $K$. pygmaea seems to be especially well adapted to warm shoot - cold root episodes, as it has a higher photosynthetic activity at 10 than $20^{\circ} \mathrm{C}$ air temperature and does not up-regulate leaf dark respiration upon soil freezing, as was observed in the grasses from warmer climates.

Keywords: adaptation to cold soil, leaf respiration, photosynthesis, soil frost, stomatal conductance, transpiration

\section{INTRODUCTION}

Plant metabolism is exposed to the thermal regime of both air and soil, which follow different diel and seasonal dynamics. Soil temperature fluctuation usually lags behind that of air temperature due to the relatively high heat capacity and low heat conductance of the soil. When the soil surface is exposed to high radiation input during the day and substantial long-wave radiation loss during the night, air and soil temperature can diverge substantially for several hours. This phenomenon of diverging soil and air temperatures occurs regularly in alpine grasslands and dwarf 
shrub heaths above the tree line in high mountains, where the reduced density of the air causes pronounced radiative cooling of soil and vegetation surfaces during the night under clear sky. On sunny mornings after clear nights air temperature may exceed soil temperature substantially (Figure 1). In alpine grasslands and dwarf shrub heaths, leaf surface temperature can exceed air and soil temperature by $15 \mathrm{~K}$ or more around noon (e.g., Körner and De Moraes, 1979). Especially in the beginning and at the end of the growing season, the shoots may then experience favorable thermal conditions for photosynthesis, while the roots are often exposed to temperatures $<5^{\circ} \mathrm{C}$ or even face frost. Under these conditions, impairment of root growth and resource uptake activity are likely, leading to a possible mismatch in the physiological activity of aboveground and belowground organs.

There are several direct and indirect pathways by which low soil temperatures may impair plant metabolism and growth, first through reductions in root growth and decreased root water/nutrient uptake, and second indirectly through reduced photosynthetic carbon gain due to stomatal closure in the course of cold-induced drought stress (DeLucia et al., 1992; Shimono et al., 2004; Alvarez-Uria and Körner, 2007). Sachs (1875) observed that plants from warmer climates wilted when exposed to cold soil of $3-5^{\circ} \mathrm{C}$, while plants from cooler climates did not. Numerous examples of plants reducing transpiration rate at soil temperatures below $10^{\circ} \mathrm{C}$ are given by Kramer (1969), but in most cases it remained unclear, whether physical constraints (increased viscosity of water) or physiological limitations (such as altered root membrane permeability) were the main causes of reduced water uptake. Some of these soil temperature effects on plant metabolism and growth seem to take place in partial or full independence of air temperature. An interesting question arising from these observations is whether plants exposed to warm air-cold soil conditions have developed specific adaptations to the frequent occurrence of steep aboveground-belowground temperature gradients.

Kramer (1942) formulated the hypothesis that plants from environments with frequent exposure to cold soil should develop

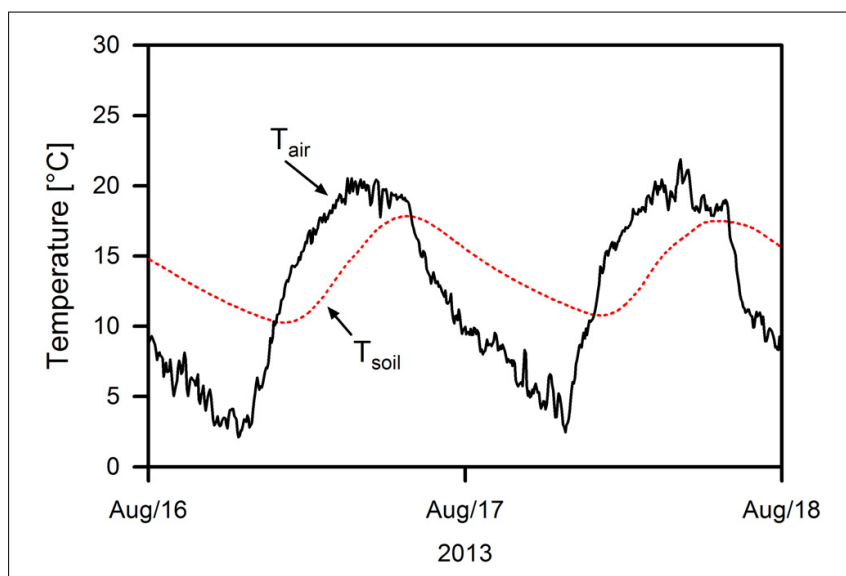

FIGURE 1 | Daily fluctuation of air and soil temperature at $1 \mathrm{~cm}$ depth in a Kobresia sward at Kema Research Station (Tibetan Plateau, 4400 m a.s.I.) on 2 days in August 2013. root systems with greater hydraulic conductivity than plants evolved in habitats with warmer soil. He showed this for water melon and cotton (warm season plants) as opposed to collards (cold season plants), and for two pine species from southern and more northern parts of the United States. In contrast, Anderson and McNaughton (1973) found no clear evidence of higher stomatal conductance, photosynthesis and transpiration rates under conditions of cold soil in plants from higher elevation as compared to lower elevation in California. Possible mechanisms are alterations in root membrane structure, greater axial hydraulic conductivity, or allocation shifts toward higher root:shoot ratios under conditions of cold soil. Various studies examining the response of root growth to low soil temperature have shown that herbs, grasses, and seedlings of woody plants reduce root growth greatly below $\sim 5^{\circ} \mathrm{C}$ and cease growth at soil temperatures of 3 to $0^{\circ} \mathrm{C}$ (e.g., Alvarez-Uria and Körner, 2007; Gaul et al., 2008; Nagelmüller et al., 2016). There is evidence of considerable species differences with respect to root growth in cold soil (Schenker et al., 2014), but no proof was found that root growth of plants from cold climates is less sensitive to temperatures between 0 and $5^{\circ} \mathrm{C}$ than that of plants from warmer climates (Alvarez-Uria and Körner, 2007).

Until now, it is unclear whether low soil temperature is as influential on plant metabolism as low air temperature. Some studies have found that, under certain conditions, soil temperature may have an even larger influence on growth than air temperature, as it influences root physiology more directly. For example, Xu and Huang (2000) found high soil temperatures to be more detrimental than high air temperatures for the growth of the grass Agrostis palustris. The photosynthesis of Picea rubens saplings was more affected by soil temperature than by air temperature (Schwarz et al., 1997). Kato et al. (2005) identified soil temperature to be more important for the net ecosystem exchange of $\mathrm{CO}_{2}$ of grasslands on the Tibetan Plateau than air temperature.

Here, we present the results of a climate chamber experiment, in which we compared the leaf gas exchange (photosynthesis, leaf dark respiration, and transpiration) and stomatal conductance of water vapor of three graminoid species (two Poaceae and one Cyperaceae) from largely different elevations (high alpine, lower alpine and lowland) and growing season temperatures while being exposed to different soil $\left(-2-25^{\circ} \mathrm{C}\right)$ and air temperatures $\left(10\right.$ and $\left.20^{\circ} \mathrm{C}\right)$. With respect to soil temperature, we distinguished between chilling temperatures (defined here as $0-10^{\circ} \mathrm{C}$ ) and sub-zero temperatures. The studied populations belong to common and widespread Eurasian calcifuge grassland species with relatively low productivity, which differ in their elevational distribution range. As we were interested in possible inheritable adaptations of the root system to cold soil, we collected swards of the three species with attached intact root system at elevations of 250, 2200, and $4400 \mathrm{~m}$ a.s.l. by soil coring. The swards with the original soil were kept for several months in the greenhouse in Göttingen to overcome assumed initial stress responses of the plants to the altered temperature and light regime in the lowlands. Thus, we investigated possible inheritable adaptations of the three populations to the local thermal regime they had experienced at 250, 2200, and $4400 \mathrm{~m}$ a.s.l. elevation in their 
life. The soil and air temperature manipulation experiments lasted only for about $14 \mathrm{~h}$ per treatment in order to investigate only short-term temperature effects and not longer-term thermal acclimation. This enabled the plants to adjust physiologically to the altered temperatures, but excluded any possible root morphological or anatomical modifications. In order to assess the physiological importance of steep soil-to-air temperature gradients for alpine grassland plants, we tested the hypotheses that (1) soil temperature affects leaf gas exchange independently of air temperature, and (2) the species from highest elevation responds in its leaf gas exchange less sensitively to cold soil than the species from warmer environments. This study provides much needed information on how a non-uniform thermal environment influences plant physiology. Since most physiological experiments are conducted in climate chambers under more or less homogeneous thermal conditions, some of the obtained results are difficult to extrapolate to field conditions, in particular in alpine environments with steep temperature gradients.

\section{MATERIALS AND METHODS}

\section{Plant Material}

The experiments were conducted with three graminoid species from the temperate and submeridional zones in Europe and Central Asia, which differ in the elevation of their main occurrence (Table 1). We chose species from the Poaceae and Cyperaceae families with similar growth habit (low-growing perennial tussock grasses with needle-shaped leaves), which have a distribution center either in the lowlands, in the lower alpine belt, or the high alpine belt in order to cover a broad altitudinal range. Deschampsia flexuosa (L.) Trin. was selected as a lowland taxon; it occurs in European grasslands and the herb layer of forests from the lowlands to the alpine belt (up to $2270 \mathrm{~m}$ a.s.l.) and rarely achieves dominance in the communities in which it is present. Nardus stricta L. (Poaceae) was chosen as a typical alpine grass species, which is present in European pastures from the lowlands to the alpine belt (up to $2600 \mathrm{~m}$ a.s.l.), but rarely penetrates the forest. The chosen high alpine sedge Kobresia pygmaea (C.B. Clarke) (Cyperaceae) dominates major parts of the Tibetan Plateau at elevations of 4000-5000 m a.s.l., the largest alpine ecosystem on earth with an extension of c. $450000 \mathrm{~km}^{2}$. Hereafter, the species will be referred to by their genus names. In the summer months, the average daily temperature amplitude ranged from 6.5 to 12.6 (Table 1 ).

In the three grasslands, soil monoliths with intact swards on top were excavated by pushing plexiglass cylinders of $15 \mathrm{~cm}$ diameter and $20 \mathrm{~cm}$ length into the soil. The cylinders were transported to the Experimental Botanical Garden of Göttingen University $\left(51^{\circ} 33^{\prime} \mathrm{N} 9^{\circ} 57^{\prime} \mathrm{E}, 181 \mathrm{~m}\right.$ a.s.l.), where the swards were kept at $15^{\circ} \mathrm{C}$ (daytime) and $13^{\circ} \mathrm{C}$ (nighttime) $(12 \mathrm{~h}$ day length) at $110-130 \mu \mathrm{mol}$ photons $\mathrm{m}^{-2} \mathrm{~s}^{-1}$ in a glasshouse (metal halid lamps: EYE Clean-Ace MT400DL/BH, Iwasaki-Electric CO., LTD., Tokyo, Japan). To ensure optimal drainage, a smaller plexiglass tube filled with fiber wicks was installed at the bottom of each cylinder (Coners et al., 2016). For removing older brown

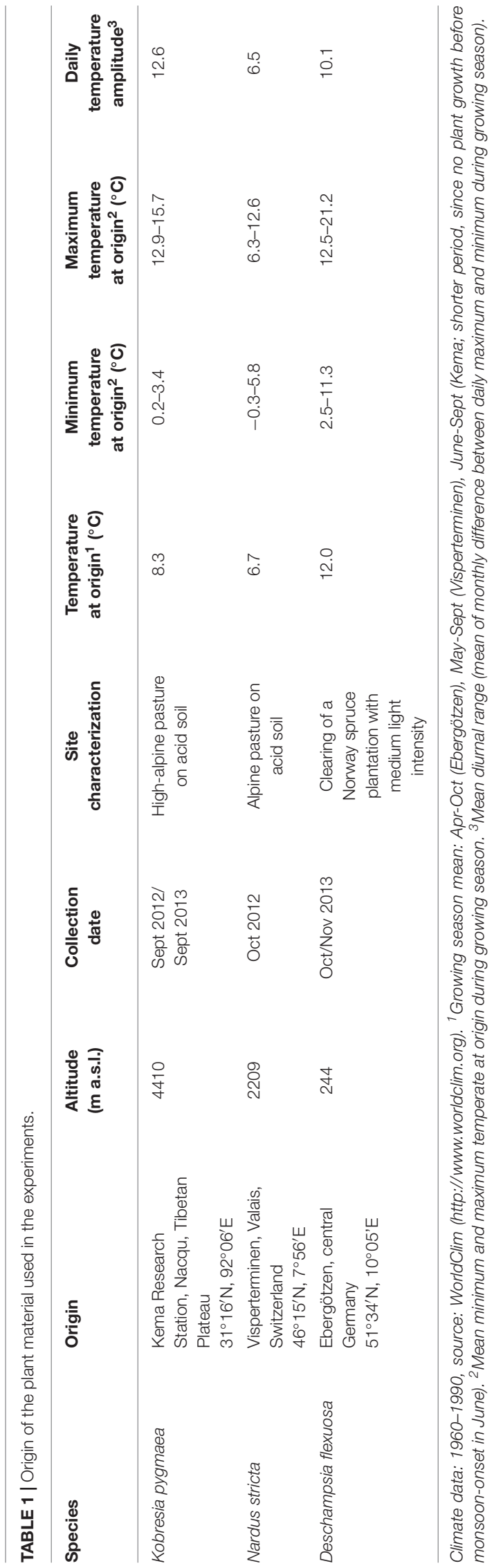


leaves and promoting the regrowth of young leaves, the swards were cut to a uniform length $\mathrm{c} .1 \mathrm{~cm}$ above the soil surface in case of Kobresia and Nardus, and to c. $3 \mathrm{~cm}$ in case of Deschampsia. The gas exchange measurements were conducted with the freshly regrown leaves, which were not older than 3 months. To avoid nutrient limitation during the experiments, plants were fertilized with a customary NPK-fertilizer (Wuxal, Manna, Düsseldorf, Germany) every 3 weeks and, if necessary, were treated with the biological insecticide Spruzit Neu (Neudorff, Emmerthal, Germany) against aphids. Plants were regularly watered in response to the water consumption of the swards for maintaining relatively uniform soil moisture levels in all monoliths throughout the experimental period.

\section{Study Design}

The experiments were conducted in two fully climatized walk-in growth chambers. Two sets of experiments were conducted, the first one with an air temperature $\left(T_{\mathrm{a}}\right)$ of $20^{\circ} \mathrm{C}$, the second one with the same plant material and the same setup 7 weeks later with $T_{\mathrm{a}}=10^{\circ} \mathrm{C}$. For the measurement campaign at $T_{\mathrm{a}}=10^{\circ} \mathrm{C}, 1$ day before starting the measurements, plants were moved to the second plant growth chamber (Johnson Controls, Milwaukee, WI, United States) which allowed to maintain lower temperatures. Between the two measurement sets, plants were kept 7 weeks at an intermediate air temperature of $15 / 13^{\circ} \mathrm{C}$ (daytime/nighttime), assuming that a possible acclimation to $20^{\circ} \mathrm{C}$ air temperature had disappeared. During the $12 \mathrm{~h}$-daylight period in both chambers, radiation intensity was 110-130 $\mu \mathrm{mol}$ photons $\mathrm{m}^{-2} \mathrm{~s}^{-1}$ and relative air humidity was $75 \%$, corresponding to a vapor pressure deficit (vpd) of $17.5 \mathrm{hPa}$ at $T_{\mathrm{a}}=20^{\circ} \mathrm{C}$ and of $12.8 \mathrm{hPa}$ at $T_{\mathrm{a}}=10^{\circ} \mathrm{C}$. We decided to keep relative air humidity constant and not vpd, as this is more realistic than a constant vpd. During nighttime, air temperature was reduced to 15 and $8^{\circ} \mathrm{C}$, respectively. Soil temperature $\left(T_{\mathrm{s}}\right)$ was manipulated in the monoliths independently from air temperature by establishing each three different $T_{\mathrm{s}}$ levels at $20^{\circ} \mathrm{C}$ air temperature $\left(5,15\right.$, and $\left.25^{\circ} \mathrm{C}\right)$ and at $10^{\circ} \mathrm{C}$ air temperature $\left(-2,5\right.$, and $\left.15^{\circ} \mathrm{C}\right)$.

The soil monoliths were placed in a randomized block design with six replicates per species and soil temperature treatment, i.e., $6 \times 3=18$ monoliths per species (54 monoliths in total). Each block consisted of three monoliths per species, which were exposed to different soil temperatures at a given air temperature level, resulting in nine monoliths per block.

To achieve the desired soil temperature, water was heated or cooled in a thermostatic water bath (RM 6 or RA 120, Lauda $\mathrm{GmbH}$, Lauda-Königshofen, Germany) and cycled through a silicone hose that was wound tightly around each cylinder (Figure 2). To minimize water temperature fluctuation within the system, monoliths and connecting hoses were insulated with $2 \mathrm{~cm}$ customary Styrofoam. In order to avoid freezing in the water bath, a customary antifreeze mixture was added to the system for the -2 and $5^{\circ} \mathrm{C}$ treatments.

During the experiments, soil temperature was monitored in each monolith with two miniature temperature sensors (Thermochron DS1922L-F5\#, Maxim integrated, San Jose, United States) inserted to $3 \mathrm{~cm}$ soil depth at the center of each monolith and logged continuously. To ensure that the desired soil temperatures were reached, $T_{\mathrm{s}}$ was measured additionally with mobile thermometers (DET 3R, Voltcraft, Wollerau, Switzerland) in the swards immediately before the beginning of a measurement. Measured soil temperatures deviated from the target values by $0.1-3.0 \mathrm{~K}$, with higher temperatures typically occurring during the first hours after switching on the light; in general, larger temperature deviations occurred at 20 than at $10^{\circ} \mathrm{C}$ air temperature (Table 2).

\section{Leaf Gas Exchange Measurements}

After an equilibration period of at least $12 \mathrm{~h}$ to a target soil temperature and additional $2 \mathrm{~h}$ of acclimation to the full light conditions in the chamber, leaf gas exchange parameters were recorded with a portable IRGA system (Li-6400, Licor,

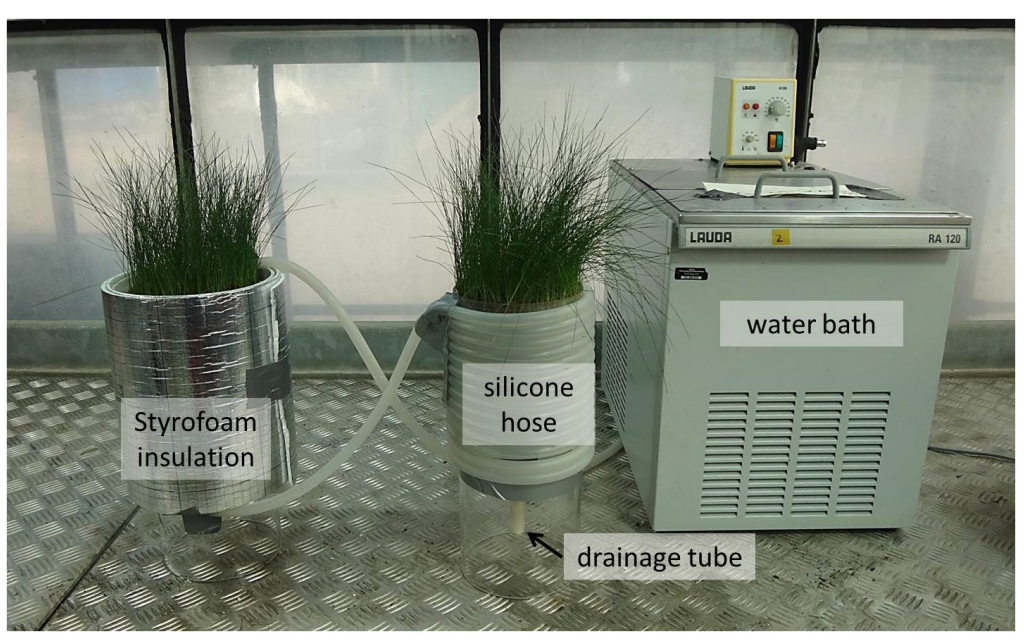

FIGURE 2 | Measurement setup. A water bath is cycling heated or cooled water through hoses wound tightly around each soil monolith with grass swards on top. The styrofoam insulation buffers against external temperature fluctuations. 
TABLE 2 | Means ( \pm standard error) of measured soil temperatures (in ${ }^{\circ} \mathrm{C}$ ) in the four soil temperature treatments $\left(-2,5,15\right.$, and $\left.25^{\circ} \mathrm{C}\right)$ established in growth chambers with either 10 or $20^{\circ} \mathrm{C}$ air temperature.

\begin{tabular}{lcc}
\hline \multirow{2}{*}{$\begin{array}{l}\text { Target soil } \\
\text { temperature }\end{array}$} & \multicolumn{2}{c}{ Air temperature level } \\
\cline { 2 - 3 } & $\mathbf{1 0 ^ { \circ } \mathbf { C }}$ & $\mathbf{2 0}^{\circ} \mathbf{C}$ \\
\hline$-2^{\circ} \mathrm{C}$ & $-2.3 \pm-0.1$ & - \\
$5^{\circ} \mathrm{C}$ & $5.1 \pm 0.0$ & $8.0 \pm 0.1$ \\
$15^{\circ} \mathrm{C}$ & $15.2 \pm 0.0$ & $16.3 \pm 0.0$ \\
$25^{\circ} \mathrm{C}$ & - & $26.3 \pm 0.1$ \\
\hline
\end{tabular}

Lincoln, Nebraska, United States). Gas exchange measurements were conducted first under ambient light intensity $(\sim 110 \mu \mathrm{mol}$ photons $\left.\mathrm{m}^{-2} \mathrm{~s}^{-1} ; \mathrm{A}_{\mathrm{amb}}\right)$, afterward at light saturation of photosynthesis ( $1500 \mu \mathrm{mol}$ photons $\left.\mathrm{m}^{-2} \mathrm{~s}^{-1} ; \mathrm{A}_{\max }\right)$, and finally in the dark (leaf dark respiration; $R_{\mathrm{d}}$ ). Leaves were allowed to acclimatize to the given light intensity for $5 \mathrm{~min}$ in every step. Leaf temperature was adjusted to air temperature, atmospheric $\mathrm{CO}_{2}$ concentration was set to $400 \mathrm{ppm}$, relative air humidity to $53 \%$.

As it was impossible to place the needle-shaped graminoid leaves in a single non-overlapping layer into the measuring chamber of $6 \mathrm{~cm}^{2}$ aperture, 20-30 living, green leaves each were spread in a single layer without foliage overlap and fixed with adhesive tape on a thin plate of opaque plastic, which contained a circular hole in the center (area $1.54 \mathrm{~cm}^{2}$ ). The plastic plate was then placed into the plexiglass chamber of the Li-6400 system. Since only the hole was illuminated by the artificial light source, photosynthetic activity should have largely been restricted to the $1.54 \mathrm{~cm}^{2}$ in the hole, while leaf dark respiration from leaf sections beyond the hole may also have been recorded. We thus assume that our net photosynthesis figures underestimate carbon dioxide assimilation to a certain extent. However, the error likely was similar in all measurements.

Stomatal conductance was measured independently of the Li-6400 measurements with a porometer (AP4, Delta-T Devices, Cambridge, United Kingdom). In a similar manner as for the Li-6400 measurements, a defined number of leaves were placed adjacent to each other to cover the cuvette aperture completely. We averaged over each three measurements of stomatal conductance per monolith and treatment.

\section{Statistical Analyses}

All data were tested for normality with a Shapiro-Wilk test. As the assumption of normality was not met, the data were transformed to ranks and all subsequent analyses performed with the transformed data. To test for significant soil temperature effects, mixed effects models were performed separately for the two air temperature treatments with species and soil temperature as fixed effects $(p \leq 0.05)$. Additional mixed effects models with the fixed factors soil, air temperature and species were run for the soil temperature treatments $T_{\mathrm{s}}=5$ and $15^{\circ} \mathrm{C}$ and the air temperature treatments $T_{\mathrm{a}}=10$ and $20^{\circ} \mathrm{C}$ (temperature difference $10 \mathrm{~K}$ for both variables) in order to test for the importance of air and soil temperature on gas exchange parameters.
Pairwise Kruskal-Wallis tests were used to test for significant differences between the treatments of a species and significant differences between species for a treatment (significance level: $p \leq 0.05$ ). If necessary, a Bonferroni correction was applied to account for multiple testing. All statistical analyses were performed with the software SAS (version 9.4, SAS Institute, Cary, NC, United States).

\section{RESULTS}

The mixed model analysis conducted separately for the two air temperature levels $\left(10\right.$ and $20^{\circ} \mathrm{C}$ ) showed that soil temperature had a significant effect on light-saturated net photosynthesis, leaf dark respiration, leaf conductance and transpiration rate only in the $10^{\circ} \mathrm{C}$ air temperature treatment (Table 3). This effect disappeared at $20^{\circ} \mathrm{C}$ air temperature (except for stomatal conductance, $p<0.05, F=3.32$ ). Mixed models including both air and soil temperature and species revealed the dominant effects of air temperature and species on leaf gas exchange, while the soil temperature effect was insignificant in all species in these overall models (Table 4).

Soil temperature shifts from 25 to 15 and $5^{\circ} \mathrm{C}$ had no significant effect on $\mathrm{A}_{\max }$ at $20^{\circ} \mathrm{C}$ air temperature in any of the species. Warmer air temperatures had a negative effect on the photosynthesis of Kobresia, i.e., $\mathrm{A}_{\max }$ was more than twice as high at $10^{\circ} \mathrm{C}$ air temperature than at $20^{\circ} \mathrm{C}$, when soil temperature was $\geq 5^{\circ} \mathrm{C}$ (Figure 3A). In contrast, the photosynthetic activity of Nardus and Deschampsia was not affected by a $T_{\mathrm{a}}$ decrease from 20 to $10^{\circ} \mathrm{C}$, when the soil was not frozen. As a consequence, Kobresia had a much lower $\mathrm{A}_{\max }$ at $20^{\circ} \mathrm{C}$ than the two Poaceae, but had a similar photosynthetic activity as Deschampsia at $10^{\circ} \mathrm{C}$, while the photosynthetic activity of Nardus was higher at any air temperature. Soil freezing $\left(-2^{\circ} \mathrm{C}\right)$ at $10^{\circ} \mathrm{C}$ air temperature resulted in very low $A_{\max }$ rates $\left(1.1-2.3 \mu \mathrm{mol} \mathrm{m}{ }^{-2} \mathrm{~s}^{-1}\right)$ in all three species (Figure 3A).

Leaf dark respiration was relatively uniform across the temperature treatments and species (mostly $1.0-1.5 \mu \mathrm{mol}$ $\mathrm{m}^{-2} \mathrm{~s}^{-1}$ ) with only few significant differences (Figure 3B). In Nardus and Deschampsia, a non-significant tendency toward somewhat higher $R_{\mathrm{d}}$ rates at 20 than $10^{\circ} \mathrm{C}$ air temperature was visible. More striking were the high $R_{\mathrm{d}}$ rates in frozen soil $\left(-2^{\circ} \mathrm{C}\right)$ at $10^{\circ} \mathrm{C}$ air temperature in these two species; Kobresia reached average $R_{\mathrm{d}}$ rates of $1.0 \mu \mathrm{mol} \mathrm{m} \mathrm{m}^{-2} \mathrm{~s}^{-1}$ at a soil temperature of $-2^{\circ} \mathrm{C}$.

Stomatal conductance was strongly reduced in all species at $-2^{\circ} \mathrm{C}$ soil temperature (Figure $3 \mathrm{C}$ ). At $10^{\circ} \mathrm{C}$ air temperature, reductions in comparison to the warmer soil treatments were up to $70 \%$ in Kobresia (to $30 \mathrm{mmol} \mathrm{m} \mathrm{m}^{-2} \mathrm{~s}^{-1}$ ), $50 \%$ in Nardus

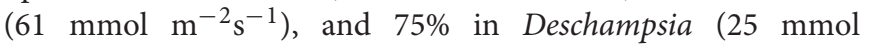
$\left.\mathrm{m}^{-2} \mathrm{~s}^{-1}\right)$. Remarkably, all three species showed higher stomatal conductance rates at $10^{\circ} \mathrm{C}$ air temperature than $20^{\circ} \mathrm{C}$ in the 5 and $15^{\circ} \mathrm{C}$ soil temperature treatments (significant differences in Kobresia, only tendencies in Deschampsia and Nardus).

The temperature response of transpiration deviated from that of photosynthesis. Transpiration rates at $20^{\circ} \mathrm{C}$ air temperature were much higher in Deschampsia than in Nardus and Kobresia 
TABLE 3 | Results of mixed model analyses for light-saturated net photosynthesis, leaf dark respiration, stomatal conductance, and transpiration rate at light saturation conducted separately for the two air temperature levels (10 and $20^{\circ} \mathrm{C}$ ) testing for the factors soil temperature, species, and the interaction of both.

\begin{tabular}{|c|c|c|c|}
\hline Effect & Df & F-value & $p$-value \\
\hline \multicolumn{4}{|l|}{$10^{\circ} \mathrm{C}$ air temperature } \\
\hline \multicolumn{4}{|c|}{ Photosynthesis at light saturation } \\
\hline Soil temperature & 2 & 44.41 & $<0.0001$ \\
\hline Species & 2 & 7.49 & 0.002 \\
\hline Soil temperature*species & 4 & 0.44 & 0.78 \\
\hline \multicolumn{4}{|l|}{ Leaf dark respiration } \\
\hline Soil temperature & 2 & 5.20 & 0.009 \\
\hline Species & 2 & 5.88 & 0.005 \\
\hline Soil temperature*species & 4 & 1.07 & 0.38 \\
\hline \multicolumn{4}{|l|}{ Stomatal conductance } \\
\hline Soil temperature & 2 & 64.17 & $<0.0001$ \\
\hline Species & 2 & 12.64 & $<0.0001$ \\
\hline Soil temperature*species & 4 & 1.54 & 0.21 \\
\hline \multicolumn{4}{|c|}{ Transpiration at light saturation } \\
\hline Soil temperature & 2 & 13.58 & $<0.0001$ \\
\hline Species & 2 & 23.99 & $<0.0001$ \\
\hline Soil temperature*species & 4 & 1.76 & 0.15 \\
\hline \multicolumn{4}{|c|}{$20^{\circ} \mathrm{C}$ air temperature } \\
\hline \multicolumn{4}{|c|}{ Photosynthesis at light saturation } \\
\hline Soil temperature & 2 & 0.92 & 0.41 \\
\hline Species & 2 & 59.72 & $<0.0001$ \\
\hline Soil temperature* species & 4 & 0.32 & 0.87 \\
\hline \multicolumn{4}{|l|}{ Leaf dark respiration } \\
\hline Soil temperature & 2 & 1.13 & 0.33 \\
\hline Species & 2 & 2.37 & 0.11 \\
\hline Soil temperature*species & 4 & 1.18 & 0.33 \\
\hline \multicolumn{4}{|l|}{ Stomatal conductance } \\
\hline Soil temperature & 2 & 3.32 & $<0.05$ \\
\hline Species & 2 & 36.09 & $<0.0001$ \\
\hline Soil temperature*species & 4 & 0.98 & 0.43 \\
\hline \multicolumn{4}{|c|}{ Transpiration at light saturation } \\
\hline Soil temperature & 2 & 0.01 & 0.99 \\
\hline Species & 2 & 19.15 & $<0.0001$ \\
\hline Soil temperature*species & 4 & 0.51 & 0.73 \\
\hline
\end{tabular}

Significant factors $(p \leq 0.05)$ are printed in bold.

$(p \leq 0.05)$, while at $10^{\circ} \mathrm{C}$ Deschampsia and Kobresia transpired at similar rates, and more than Nardus, unless the soil was frozen (Figure 3D). In frozen soil $\left(-2^{\circ} \mathrm{C}\right)$ Kobresia and Nardus exhibited lower transpiration rates $\left(\sim 0.5 \mathrm{mmol} \mathrm{H}_{2} \mathrm{O} \mathrm{m}^{-2} \mathrm{~s}^{-1}\right)$ than Deschampsia $\left(\sim 0.75 \mathrm{mmol} \mathrm{m}^{-2} \mathrm{~s}^{-1}\right)$.

\section{DISCUSSION}

\section{Chilling Sensitivity of Photosynthesis and Stomatal Conductance}

In our study with three graminoids from a broad range of elevations, the soil temperature effect on photosynthesis and transpiration was in all species weak at soil temperatures $\geq 5^{\circ} \mathrm{C}$, even though the investigated temperature range in the
TABLE 4 | Results of mixed model analyses for light-saturated net photosynthesis, leaf dark respiration, stomatal conductance, and transpiration rate at light saturation for two soil $\left(5\right.$ and $15^{\circ} \mathrm{C}$ ) and air temperature treatments (10 and $20^{\circ} \mathrm{C}$ ) with $10 \mathrm{~K}$ temperature difference testing for the factors soil temperature, air temperature, species, and their interactions.

\begin{tabular}{|c|c|c|c|}
\hline Effect & Df & F-value & $p$-value \\
\hline \multicolumn{4}{|l|}{ Photosynthesis at light-saturation } \\
\hline Soil temperature & 1 & 0.94 & 0.34 \\
\hline Air temperature & 1 & 6.86 & 0.01 \\
\hline Species & 2 & 33.35 & $<0.0001$ \\
\hline Soil temperature*air temperature & 1 & 0.07 & 0.80 \\
\hline Soil temperature*species & 2 & 0.05 & 0.95 \\
\hline Air temperature*species & 2 & 4.21 & 0.02 \\
\hline Soil temperature*air temperature* species & 2 & 0.60 & 0.55 \\
\hline \multicolumn{4}{|l|}{ Leaf dark respiration } \\
\hline Soil temperature & 1 & 1.33 & 0.25 \\
\hline Air temperature & 1 & 21.07 & $<0.0001$ \\
\hline Species & 2 & 3.38 & 0.04 \\
\hline Soil temperature*air temperature & 1 & 0.58 & 0.45 \\
\hline Soil temperature*species & 2 & 2.80 & 0.07 \\
\hline Air temperature*species & 2 & 0.24 & 0.78 \\
\hline Soil temperature*air temperature*species & 2 & 0.23 & 0.80 \\
\hline \multicolumn{4}{|l|}{ Stomatal conductance } \\
\hline Soil temperature & 1 & 2.64 & 0.11 \\
\hline Air temperature & 1 & 45.64 & $<0.0001$ \\
\hline Species & 2 & 13.85 & $<0.0001$ \\
\hline Soil temperature*air temperature & 1 & 0.47 & 0.49 \\
\hline Soil temperature*species & 2 & 1.55 & 0.22 \\
\hline Air temperature* species & 2 & 5.41 & 0.01 \\
\hline Soil temperature*air temperature*species & 2 & 0.06 & 0.94 \\
\hline \multicolumn{4}{|l|}{ Transpiration at light-saturation } \\
\hline Soil temperature & 1 & 0.16 & 0.69 \\
\hline Air temperature & 1 & 34.23 & $<0.0001$ \\
\hline Species & 2 & 21.33 & $<0.0001$ \\
\hline Soil temperature*air temperature & 1 & 0.01 & 0.91 \\
\hline Soil temperature*species & 2 & 0.15 & 0.86 \\
\hline Air temperature*species & 2 & 4.30 & 0.02 \\
\hline Soil temperature*air temperature* species & 2 & 0.12 & 0.88 \\
\hline
\end{tabular}

Significant factors $(p<0.05)$ are printed in bold.

experiments was large $\left(5-25^{\circ} \mathrm{C}\right)$. A positive effect of higher $T_{\mathrm{s}}$ on gas exchange rates was only noticed for stomatal conductance in Deschampsia, which increased between 5 and $25^{\circ} \mathrm{C}$ (differences only partly significant, Figure $3 \mathrm{C}$ ). This disproves our hypothesis (1) on a general air temperature-independent effect of soil temperature on gas exchange. Our climate chamber results also do not confirm the assumption that adaptation to low soil temperatures is physiologically more important than adaptation to low air temperature, as has been proposed by e.g., Schwarz et al. (1997). Similar results were obtained by Anderson and McNaughton (1973) who found neither decreases in net photosynthesis nor transpiration rate for 12 herb and dwarf shrub species, when soil temperature was reduced from 20 to $3^{\circ} \mathrm{C}$. A few of the 57 plant species investigated by Döring (1935) also showed no reduction in water transport, when 


\section{A}

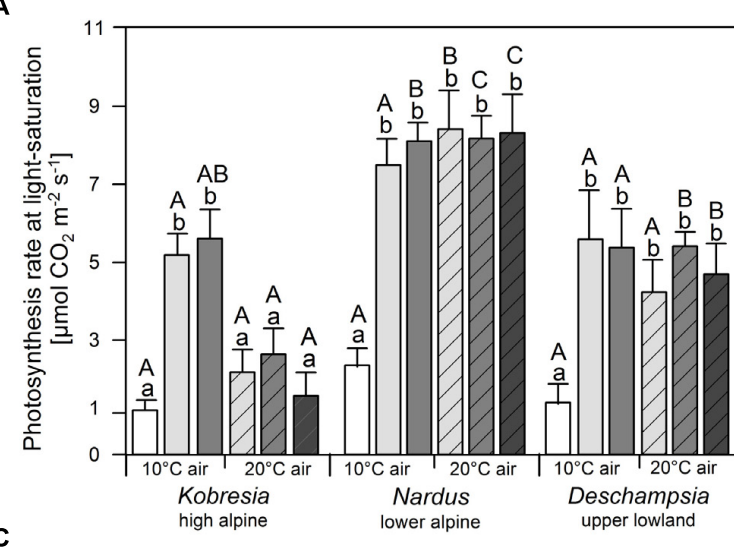

C

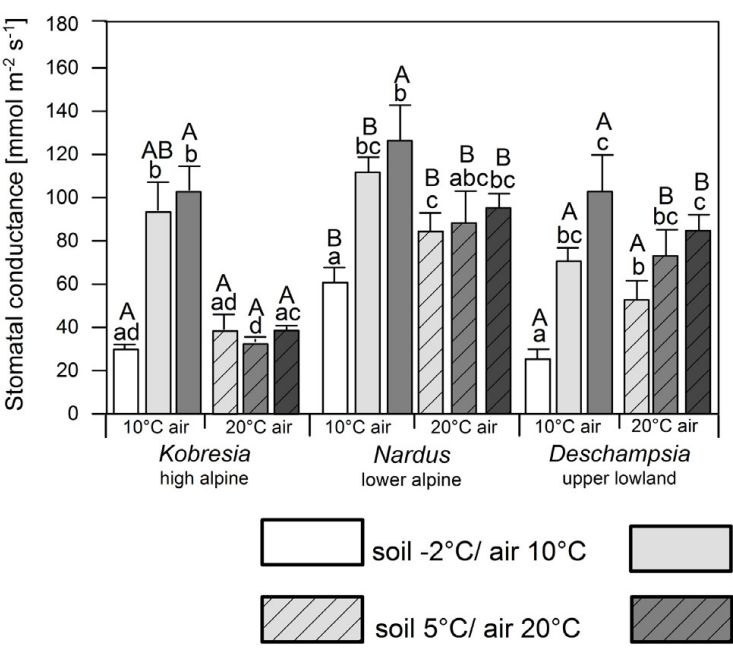

B

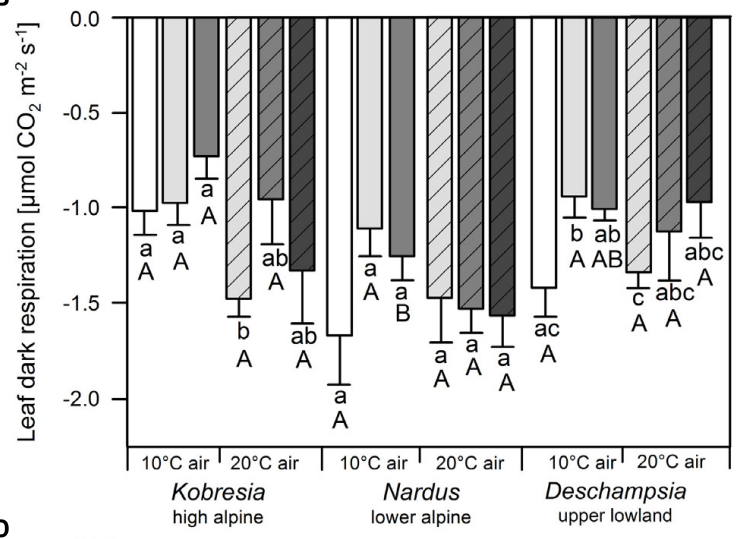

D

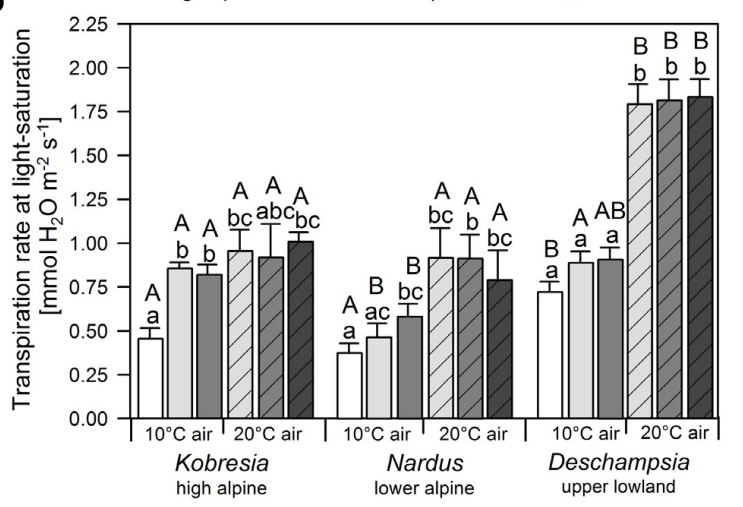

soil $5^{\circ} \mathrm{C} /$ air $10^{\circ} \mathrm{C}$

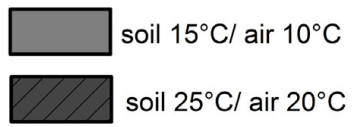

FIGURE 3 | (A) Photosynthesis at light saturation (1500 $\mu$ mol photons $\left.\mathrm{m}^{-2} \mathrm{~s}^{-1}\right)$, (B) leaf dark respiration, (C) stomatal conductance, and (D) transpiration at light saturation of Kobresia pygmaea, Deschampsia flexuosa, and Nardus stricta in the two air temperature $\left(10\right.$ and $\left.20^{\circ} \mathrm{C}\right)$ and four soil temperature $\left(-2,5,15\right.$, and $\left.25^{\circ} \mathrm{C}\right)$ treatments. Small letters indicate significant differences $(p \leq 0.05)$ between treatments for one species. Capital letters indicate significant differences $(p \leq 0.05)$ between species within a treatment. Error bars indicate standard errors, $n=6$.

exposed to low root temperatures close to the freezing point, but the majority did. Several other authors reported reductions in water uptake or transpiration and photosynthesis at low soil temperatures in tropical or subtropical and temperate species (e.g., Kramer, 1942; Böhning and Lusanandana, 1952; Cox and Boersma, 1967). Part of the discrepancy in results on the soil temperature influence may be due to different experimental conditions, i.e., plants in soil vs. hydroponics and plants taken from the wild vs. plants grown in the glasshouse. Only few studies have been conducted with graminoids, to which our results can be compared. For example, rice plants reared in hydroponics reduced their transpiration rate at rhizosphere temperatures of $13^{\circ} \mathrm{C}$ compared to $25^{\circ} \mathrm{C}$ (Kuwagata et al., 2012). Similarly, Shimono et al. (2004) found a reduced stomatal conductance of rice in cold rooting medium. These results may point at a particularly high soil temperature sensitivity of graminoids from warm environments. The $\mathrm{C} 4$ grass Andropogon gerardii reduced photosynthesis greatly when grown at soil temperatures of 5 and $10^{\circ} \mathrm{C}$ compared to $15-40^{\circ} \mathrm{C}$ (DeLucia et al., 1992), which likely was caused by water stress due to root chilling. It appears that chilling effects on the photosynthesis and stomatal conductance of graminoids do occur, but seem not to be omnipresent in plants from cool environments.

That reduction in soil temperature from 25 to $5^{\circ} \mathrm{C}$ (at $20^{\circ} \mathrm{C}$ air temperature), or from 15 to $5^{\circ} \mathrm{C}$ (at $T_{\mathrm{a}}=10^{\circ} \mathrm{C}$ ), did not significantly decrease transpiration rate in our experiments, is at first sight surprising, as root water uptake apparently was not impaired by the substantially higher viscosity of water in cold soil. The viscosity of water at $15^{\circ} \mathrm{C}$ is about $33 \%$, and at $5^{\circ} \mathrm{C}$ even c. $70 \%$ higher than at $25^{\circ} \mathrm{C}$. This hinders water movement not only in the rhizosphere, but also in the root apoplasm and the xylem conduits of root and shoot. A possible explanation of our findings is that aquaporin activity in root membranes was higher in the colder treatments, or alternatively, the driving soil-to-leaf water potential gradient was larger, possibly due to lowered leaf water potential. In the absence of data on aquaporin activity and leaf water status, this must however remain speculative.

Leaf dark respiration differed in our experiments only little between the three species under a given thermal regime, which contrasts with photosynthesis and leaf conductance that revealed 
greater species differences. This shows that graminoids from cold and warm climates, when grown at the same temperature, converge in their leaf respiratory activity and maintain similar rates, even though they must have developed adaptations to largely different thermal regimes. In addition, the species from lower elevations (D. flexuosa and N. stricta) were in general not more responsive to soil temperatures $<10^{\circ} \mathrm{C}$, i.e., the corresponding change in gas exchange was not larger, than in the high-alpine species K. pygmaea. Adaptation to warmer environments thus did not lead to greater sensitivity of stomatal conductance and photosynthesis to cold soil, and the elevation of plant origin did not influence the response in our sample of graminoid species. While K. pygmaea is distributed only above $\sim 3000 \mathrm{~m}$ a.s.l. (Flora of China, 2015), N. stricta is abundant in both the lowlands and in the alpine belt to $>2000 \mathrm{~m}$, and D. flexuosa is most widespread in the lowlands and lower mountain ranges. The results from this study thus seem not supportive of the hypothesis of Kramer (1942) who predicted that species native to cooler climates should possess root systems with greater water permeability at low soil temperatures than plants native to warmer climates. However, the three species of our study are not sufficient to test this hypothesis.

\section{What Is Different in High-Alpine Kobresia?}

The findings suggest that Kobresia has not only a low temperature optimum of photosynthesis, but also that the species apparently is largely insensitive to soil cooling between 15 and $5^{\circ} \mathrm{C}$.

Our gas exchange data suggest that the $\mathrm{A}_{\max }$ of Kobresia was reduced at $20^{\circ} \mathrm{C}$ due to both, a higher dark respiration rate of the leaves, and a greatly reduced stomatal conductance compared to $10^{\circ} \mathrm{C}$ air temperature. Since soil moisture was kept at favorable, non-limiting levels in the monoliths throughout the experiments, and cold soil cannot play a role, it was possibly stomatal sensitivity to a higher vpd that caused partial stomatal closure in Kobresia at $20^{\circ} \mathrm{C}$ air temperature. This interpretation would be in line with the observation that soil temperatures between 5 and $25^{\circ} \mathrm{C}$ had no influence on stomatal conductance, photosynthesis and transpiration in this high alpine species. The sedge Carex curvula in the alpine grasslands of the high Alps has a temperature optimum of photosynthesis of $15^{\circ} \mathrm{C}$ at $2300 \mathrm{~m}$ a.s.l., when radiation was low $\left(200 \mu \mathrm{mol} \mathrm{m} \mathrm{m}^{-2} \mathrm{~s}^{-1}\right)$, but a much higher optimum of $20-25^{\circ} \mathrm{C}$ at $1500 \mu \mathrm{mol} \mathrm{m} \mathrm{s}^{-2}$ (Körner, 1982). Since our plants were grown at relatively low light intensities in the chambers $\left(110-130 \mu \mathrm{mol} \mathrm{m} \mathrm{m}^{-2} \mathrm{~s}^{-1}\right)$ in order to be able to reduce soil temperatures to low values in the chamber, it is likely that the photosynthetic apparatus of the experimental plants was adapted to these light conditions, which may relate to the low temperature optimum of $\mathrm{A}_{\max }$. During rainless weather, insolation can be much higher on the Tibetan Plateau, suggesting that the temperature optimum of photosynthesis in Kobresia may also be higher in the field than observed in our experiment. In order to assess the relevance of the observed adaptive responses to cold soil in Kobresia under natural conditions, additional gas exchange measurements in the field during days with large air-to-soil temperature gradients are needed.

\section{Freezing Sensitivity of Gas Exchange}

In contrast to chilling effects, soil freezing $\left(-2^{\circ} \mathrm{C}\right)$ had a pronounced effect on the stomatal conductance, photosynthesis and (in Kobresia) transpiration rate of all three graminoid species in a similar manner as it is observed for conifers (Havranek and Tranquillini, 1995; Schaberg et al., 1995). The reduction in transpiration upon soil cooling from +5 to $-2^{\circ} \mathrm{C}$ can well be explained by stomatal closure, probably caused by leaf dehydration due to impaired water uptake. However, stomatal closure explains only part of the concomitant reduction in photosynthesis. In Nardus and Deschampsia, an increase in leaf respiration has contributed to the reduction in net photosynthesis rate, but not so in Kobresia. This suggests that non-stomatal mechanisms such as decreased Calvin cycle enzyme activity or electron transport (Öquist et al., 1983; Teskey et al., 1995; Schwarz et al., 1997) may have played a role in this high-alpine species.

Freezing temperatures in the soil reduced photosynthesis of the three species, but not leaf dark respiration. In fact, $R_{\mathrm{d}}$ was equally high, or even higher, at $-2^{\circ} \mathrm{C}$ than at 5 or $15^{\circ} \mathrm{C}$ soil temperature, suggesting that stomata closed due to impaired water supply from the soil, which affected photosynthesis but not respiration. Mitochondrial respiration in the leaves apparently was up-regulated in Nardus and Deschampsia in response to the stress imposed by soil freezing. This could be a direct response to leaf water status deterioration, or caused by a hypothetical chemical signal from the frost-exposed roots.

\section{CONCLUSION}

Contrary to expectation, we could not detect an air temperature-independent effect of cool, non-frozen soil on the photosynthesis and stomatal conductance of the three graminoids from variable altitudes (hypothesis 1 ). This suggests that periods with warm shoot but cold root system especially at high elevations in the morning hours may allow a relatively high photosynthetic activity despite cold soil. The physiological mechanisms which allow these graminoids to maintain a relatively high root water uptake at a soil temperature of $5^{\circ} \mathrm{C}$ still need further investigation.

Our data further suggest that the high-alpine sedge $K$. pygmaea is especially well adapted in its gas exchange to microclimatic conditions with warm shoots and cold roots. While the other two species from warmer climates also seem to be able to cope quite well with cold soil, they apparently lack some adaptations of Kobresia (hypothesis 2). The sedge differed from the other species in that it did not up-regulate leaf dark respiration in frozen soil. This may indicate that Nardus and Deschampsia are developing a negative C balance during soil freezing earlier than Kobresia.

Our results reveal only inheritable adaptations in leaf gas exchange to low soil and air temperatures, since we conducted an experiment under uniform climatic conditions, in which the plants were grown for several months under lowland conditions 
prior to measurement. Moreover, the results of this experimental study can hardly be extrapolated to the field, as a species' ability to cope with soil and air temperature variation will certainly be greater under natural conditions. Short-term reversible responses due to phenotypic plasticity will add to inherited adaptations, which were not studied here.

\section{DATA AVAILABILITY}

All datasets generated for this study are included in the manuscript and/or the supplementary files.

\section{AUTHOR CONTRIBUTIONS}

LG conducted the climate chamber experiments and did most of the data analysis and manuscript preparation. HC, DH, and SW retrieved the sward monoliths from the field and developed and

\section{REFERENCES}

Alvarez-Uria, P., and Körner, C. (2007). Low temperature limits of root growth in deciduous and evergreen temperate tree species. Funct. Ecol. 21, 211-218. doi: 10.1111/j.1365-2435.2007.01231.x

Anderson, J., and McNaughton, S. (1973). Effects of low soil temperature on transpiration, photosynthesis, leaf relative water content, and growth among elevationally diverse plant populations. Ecology 54, 1220-1233. doi: 10.2307/ 1934185

Böhning, R. H., and Lusanandana, B. (1952). A comparative study of gradual and abrupt changes in root temperature on water absorption. Plant Physiol. 27, 475-488. doi: 10.1104/pp.27.3.475

Coners, H., Babel, W., Willinghöfer, S., Biermann, T., Köhler, L., Seeber, E., et al. (2016). Evapotranspiration and water balance of high-elevation grassland on the tibetan plateau. J. Hydrol. 533, 557-566. doi: 10.1016/j.jhydrol.2015. 12.021

Cox, L. M., and Boersma, L. (1967). Transpiration as a function of soil temperature and soil water stress. Plant Physiol. 42, 550-556. doi: 10.1104/pp.42.4.550

DeLucia, E. H., Heckathorn, S. A., and Day, T. A. (1992). Effects of soil temperature on growth, biomass allocation and resource acquisition of Andropogon gerardii vitman. New Phytol. 120, 543-549. doi: 10.1111/j.1469-8137.1992.tb01804.x

Döring, B. (1935). Die temperaturanhängigkeit der wasseraufnahme und ihre ökologische bedeutung. Zschr. F. Bot. 28, 305-338.

Flora of China (2015). Flora of China. http://www.efloras.org/florataxon.aspx? flora_id=2\&taxon_id=200026858

Gaul, D., Hertel, D., and Leuschner, C. (2008). Effects of experimental soil frost on the fine-root system of mature norway spruce. J. Plant. Nutr. Soil Sci. 171, 690-698. doi: 10.1002/jpln.200700284

Havranek, W. M., and Tranquillini, W. (1995). "Physiological processesduring winter dormancy and their ecological significance," in Ecophysiology of Coniferous Forests, eds W. K. Smith and T. M. Hinckley (San Diego: Academic Press), 95-124.

Kato, T., Hirota, M., Tang, Y., Cui, X., Li, Y., Zhao, X., et al. (2005). Strong temperature dependence and no moss photosynthesis in winter $\mathrm{CO}_{2}$ flux for a Kobresia meadow on the qinghai-tibetan plateau. Soil Biol. Biochem. 37, 1966-1969. doi: 10.1016/j.soilbio.2005.02.018

Körner, C. (1982). $\mathrm{CO}_{2}$ exchange in the alpine sedge carex curvula as influenced by canopy structure, light and temperature. Oecologia 53, 98-104. doi: 10.1007/ BF00377142

Körner, C., and De Moraes, J. A. P. V. (1979). Water potential and diffusion resistance in alpine cushion plants on clear summerdays. Oecol. Plant. 14, $109-120$.

Kramer, P. J. (1942). Species differences with respect to water absorption at low soil temperatures. Am. J. Bot. 29, 828-832. doi: 10.1002/j.1537-2197.1942.tb10287.x supervised the experimental design. CL had the initial idea and wrote major parts of the manuscript.

\section{FUNDING}

Field work on Kobresia was funded through the DFG (German Science Foundation) priority programme 1372 "Tibetan Plateau - Formation - Climate - Ecosystems (TiP)" under the contract Le 762/12-1,2.

\section{ACKNOWLEDGMENTS}

We would like to thank the municipality of Visperterminen, Switzerland, for the permission to retrieve soil monoliths. Special thanks go to Regina Helbig for taking care of the experimental plants. We are grateful to two reviewers who helped to improve the paper through constructive criticism of an earlier draft.

Kramer, P. J. (1969). Plant and Soil Water Relations. A Modern Synthesis. New York, NY: McGraw-Hill.

Kuwagata, T., Ishikawa-Sakurai, J., Hayashi, H., Nagasuga, K., Fukushi, K., Ahamed, A., et al. (2012). Influence of low air humidity and low root temperature on water uptake, growth and aquaporin expression in rice plants. Plant. Cell Physiol. 53, 1418-1431. doi: 10.1093/pcp/pcs087

Nagelmüller, S., Kirchgessner, N., Yates, S., Hiltpold, M., and Walter, A. (2016). Leaf length tracker: a novel approach to analyse leaf elongation close to the thermal limit of growth in the field. J. Exp. Bot. 67, 1897-1906. doi: 10.1093/jxb/erw003

Öquist, G. (1983). Effects of low temperature on photosynthesis. Plant Cell Environ. 6, 281-300.

Sachs, J. (1875). Geschichte Der Botanik Vom 16. Jahrhundert Bis 1860. München: Oldenbourg.

Schaberg, P. G., Wilkinson, R. C., Shane, J. B., Donnelly, J. R., and Cali, P. F. (1995). Winter photosynthesis of red spruce from three vermont seed sources. Tree Physiol. 15, 345-350. doi: 10.1093/treephys/15.5.345

Schenker, G., Lenz, A., Körner, C., and Hoch, G. (2014). Physiological minimum temperatures for root growth in seven common european broad-leaved tree species. Tree Physiol. 34, 302-313. doi: 10.1093/treephys/tpu003

Schwarz, P., Fahey, T., and Dawson, T. (1997). Seasonal air and soil temperature effects on photosynthesis in red spruce (Picea rubens) saplings. Tree Physiol. 17, 187-194. doi: 10.1093/treephys/17.3.187

Shimono, H., Hasegawa, T., Fujimura, S., and Iwama, K. (2004). Responses of leaf photosynthesis and plant water status in rice to low water temperature at different growth stages. Field Crop. Res. 89, 71-83. doi: 10.1016/j.fcr.2004.01.025

Teskey, R. O., Sheriff, D. W., Hollinger, D. Y., and Thomas, R. B. (1995). "External and internal factors regulating photosynthesis," in Resource Physiology of Conifers, eds W. K. Smith and T. M. Hinckley (San Diego: Academic Press), 105-140.

$\mathrm{Xu}$, Q., and Huang, B. (2000). Growth and physiological responses of creeping bentgrass to changes in air and soil temperatures. Crop Sci. 40, 1363-1368. doi: $10.2135 /$ cropsci2000.4051363x

Conflict of Interest Statement: The authors declare that the research was conducted in the absence of any commercial or financial relationships that could be construed as a potential conflict of interest.

Copyright (c) 2019 Göbel, Coners, Hertel, Willinghöfer and Leuschner. This is an open-access article distributed under the terms of the Creative Commons Attribution License (CC BY). The use, distribution or reproduction in other forums is permitted, provided the original author(s) and the copyright owner(s) are credited and that the original publication in this journal is cited, in accordance with accepted academic practice. No use, distribution or reproduction is permitted which does not comply with these terms. 